\title{
In Vitro Regeneration of Grass Pea (Lathyrus sativus L.) from Cotyledonary Node Explants
}

\author{
Diriba Tesfaye (Corresponding author) \\ Department of Dry land Crop Science, Jigjiga University, Jigjiga, Ethiopia \\ Kassahun Bantte \\ Department of Plant biotechnology, Jimma University, Jimma, Ethiopia
}

Tewodros Tadesse

Jimma Agricultural Research Center, Jimma, Ethiopia

Received: February 9, 2016 Accepted: February 10, 2017 Published: July 24, 2017

Doi: 10.5296/jab.v5i2.9121 URL: http://doi.org/10.5296/ jab.v5i2.9121

\begin{abstract}
Full potential of grass pea has not been utilized because of the presence of the neurotoxin amino acid $\beta$-N-oxalyl-L- $\alpha \beta$-diaminopropionic acid (ODAP/BOAA). Conventional breeding and other approaches have not been successful in reducing the toxin. Integration of in vitro techniques can contribute significantly to meet the challenge. Therefore, this study was carried out to evaluate the in vitro regeneration capacity of grass pea genotypes. Shoot initiation, multiplication and rooting of IVAT-LS-690 were conducted using completely randomized design with five replications. Genotypes were treated with BAP and NAA for shoot initiation while BAP and Kn Combination were used for multiplication. Different concentrations of IBA and IAA were used for rooting. Shoot proliferation percentage was the highest (100\%) for IVAT-LS-690, on Murashige and Skoog (MS) medium augmented with 2.0 $\mathrm{mg} / \mathrm{l} \mathrm{BAP}+0.1 \mathrm{mg} / \mathrm{lNAA}$.For in vitro shoot multiplication, best results were obtained on concentrations of $3 \mathrm{mg} / \mathrm{l} \mathrm{BAP}+1 \mathrm{mg} / \mathrm{l} \mathrm{Kn}$ with maximum shoot number per explants (11.5). High number of roots per shoot (6) and percent of rooted shoot $(86.66 \%)$ were obtained from $1 / 2$ MS medium supplemented with $0.5 \mathrm{mg} / \mathrm{l} \mathrm{IBA}$. This study inferred that both genotype and BAP levels play a crucial role for shoot regeneration capacity and the optimum hormonal combination for grass pea is genotype specific.
\end{abstract}


Keywards: Cotelydenary node, in vitro regeneration, BAP, IBA,ODAP/BOAA

\section{Introduction}

Grass pea (Lathyrussativus L.) belongs to the Leguminosae. It is one of the 150 species in the genus Lathyrus and diploid with a chromosome number of $2 \mathrm{n}=14$ (Smartt, 1990). The crop is an annual herbaceous vine with stems ranging from 20 to $90 \mathrm{~cm}$ in length and pinnately veined leaves with two leaflets. The flowers are solitary, auxiliary and are borne on long peduncles with corollas ranging from 12 to $24 \mathrm{~mm}$ in length and are reddish-purple, pink, and blue or white (Campbell \& Clayton, 1997).

Several Lathyrus species and in particular Lathyrus sativus (grass pea) have great agronomic potential as grain and forage legume, especially in drought conditions. It is considered as one of the most promising sources of calories and protein for the enormous and expanding populations of drought-prone and marginal areas of Asia and Africa (Girma, 2010). It is virtually the only species that can yield high protein food and feed under these conditions. The crop is superior in yield, protein value, nitrogen fixation, and drought tolerance than other legume (Barik et al., 2005).

Lathyrus species have also a considerable potential in crop rotation, improving soil physical conditions, reducing the amount of disease and weed populations, with the overall reduction of production costs (VazPatto et al., 2005). In addition to these benefits, it is an efficient nitrogen fixer and improves soil fertility by adding around $67 \mathrm{~kg} / \mathrm{ha}$ of nitrogen in a single season, thereby conferring yield and protein benefits for the subsequent non-legume crop (Wang et al., 2000).

In Ethiopia, grass pea is commonly cultivated as food and feed crop because of its resistance to drought, flood, and moderate salinity (Wuletaw, 2003). It performs well under adverse agricultural conditions, and its many cultivars possess different attributes including the ability to resist both drought and flooding, high climatic adaptability and the ability to grow in cool climates and at high altitudes (Tiwari et al., 1996).

It is the fifth most important pulse crop in Ethiopia following faba bean (Viciafaba), field pea (Pisum sativum), haricot bean (Phaseolus vulgaris) and chickpea (Cicer arietinum) (Dejene and Lijalem, 2012). It occupies $8.7 \%$ of the total area and $7.6 \%$ of the total production of food legumes in Ethiopia (Wuletaw \& Endashaw, 2001). Despite, the problem caused by the neurotoxin b-N-oxalyl-L-a,bdiaminopropionic acid (ODAP), the area for grass pea cultivation has increased recently(159,731 ha), exceeding the total area occupied by the highly expensive pulse crop, lentil (94,946 ha)(CSA, 2010). This suggests that the crop is becoming more important than ever in the farming system.

Even though, its cultivation requires the least crop management and the crops can provide a lot of benefits, its full potential has not been utilized because of the presence of the neurotoxic amino acid $\beta$-N-oxalyl-L- $\alpha \beta$-diaminopropionic acid (ODAP/BOAA) which causes neurolathyrism in human beings on prolonged consumption (Yigzaw et al., 2001).

According to Dejene and Lijalem (2012), in Ethiopia different attempts were made to meet the challenges of ODAP. These include hybridization programs aimed at toxin-free or low toxin content varieties, introduction of low-toxin or toxin-free varieties from international source, and collection, characterization, and evaluation of local farmer's varieties (landraces) 
for low toxin content. All these approaches were mainly based on conventional breeding methods and have not been successful in developing a variety with low ODAP content.

Following the advent of modern approach for crop improvement different researches were done to solve the problem of ODAP. Zambre et al. (2002) found high amounts of somaclonal variation for ODAP contents through in vitro selection techniques. An in vitro protocol for fast production of advanced progenies significantly shortening generation cycles has also been developed in grass pea ( $L$. sativus), over three generations per year can be obtained instead of the normal two allowing a faster progress in the Lathyrus improvement through assisting conventional breeding (Ochatt et al., 2002). Sachdev et al. (1995)cloned a coding sequence with ODAP-metabolizing properties from a soil microbe which will be useful for genetic transformation. However, VazPatto et al. (2006) reported that genetic transformation using Agrobacterium tumefaciensas a vector has resulted in limited success due to the absence of in vitro plant regeneration protocol without an intermediate callus phase. Considering the absence of an adventitious plant production system in grass pea, an alternative callus-free regeneration could be achieved using cotyledonary node explants, which has already been exploited for Agrobacterium-mediated transformation of several grain legumes including kidney bean (Babaoglu et al., 2000).

Hence, to exploit the potential of grass pea as a source of multiple stress- tolerant genes for general crop improvement and to meet the challenges of ODAP, in vitro techniques such as, somatic hybridization, somaclonal variation and genetic transformation can contribute significantly. In addition to this an in vitro culture of this crop can assist breeding through fast production of advanced progenies to shortening generation cycles (Olhoft et al., 2002). To this end, testing the in vitro regeneration capacity of genotypes is a prerequisite.

Therefore, this work was done with the following objectives: 1) To evaluate the in vitro regeneration capacity of cotyledonary node explants of four grass pea (Lathyrus sativus) genotypes; 2)To determine the suitable cytokininis (BAP \& Kn) and the optimum concentration for in vitro shoot development of selected genotype; and 3i) To determine the effect of different auxins (IAA \& IBA) and their concentration on in vitro rooting of selected genotype

\section{Materials and Methods}

The study was conducted in the tissue culture laboratory of Jimma University College of Agriculture and Veterinary Medicine (JUCAVM, Ethiopia) from November 2012 to November 2013.

\subsection{Experimental Materials}

For these study four genotypes of grass pea, namely IVATLS-LS -B2, IVATLS-LS -B1, IVAT-LS- 690, and IVAT-LS-655 were obtained from Debrezeit Agricultural Research Center (Bishoftu, Ethiopia). These genotypes are characterized by better agronomic performance except their ODAP limitation.

\subsection{Explants Preparation and Sterilization}

Dry seeds of each genotype were kept under running tap water for $30 \mathrm{~min}$, in separate container, followed by an 8-minute treatment with 5\% tween -20 and rinsed five to six times with double-distilled water. Then the seeds were surface-sterilized with a $70 \%$ ethanol for 
$30-45 \mathrm{~s}$, followed by five rinses in autoclaved double-distilled water. The surface-sterilized seeds of each genotype were inoculated in separate screw-capped jars on Murashige and Skoog (MS) basal media (1962) without plant growth regulator (PGR) gelled with $0.8 \%(\mathrm{w} / \mathrm{v})$ agar. The seeds were cultured at $26 \pm 2{ }^{\circ} \mathrm{C}$ with $25 \mu \mathrm{mol} \mathrm{m} \mathrm{m}^{-2} \mathrm{~s}^{-1}$ photon flux density provided by cool white fluorescent tubes. Then seven-day-old seedlings were served as source of explants.

\subsection{Media Preparation}

MS basal medium was used along with the proper type and concentration of PGRs throughout the experiments. All macronutrients, micronutrients, Fe-Na-EDTA, $\mathrm{FeSO}_{4}$ mixture and vitamins were used. Stock solutions for each of the MS components were prepared separately by weighing a proper amount of powder of each component and completely dissolved in double distilled water. Then they were stored in refrigerator at $4^{0} \mathrm{C}$ for a maximum of one month. The plant growth regulator stocks were prepared in $1 \mathrm{mg} / \mathrm{ml}$ concentration. After weighing an accurate amount of BAP, Kn., IAA, and IBA ready- made powder, they were allowed to completely dissolved in double distilled water by using $\mathrm{NaOH}$ (for auxins) and $\mathrm{HCl}$ (for cytokinins) and stored at $4^{\circ} \mathrm{C}$ in refrigerator.

The culture media were prepared by taking the appropriate volumes of the stock solutions. Sucrose $(30 \mathrm{~g} / \mathrm{l})$ was added in the media as a carbon source. Then the $\mathrm{pH}$ was adjusted to $5.8 \pm$ 2 using either $1 \mathrm{~N} \mathrm{NaOH}$ or $1 \mathrm{~N} \mathrm{HCl}$ solution before $0.8 \% \mathrm{w} / \mathrm{v}$ agar was added. It was then melted and dispensed into the culture vessels and finally autoclaved at a temperature of 121 ${ }^{\circ} \mathrm{C}$ with a pressure of 15 Psi for 20 minutes. Filter sterilization was used for IAA as it is less stable and heat labile for autoclaving.

\subsection{Culturing and Culture Conditions}

The cotyledonary node explants cultured on MS medium supplemented with different PGRs were maintained on shoot initiation medium. The culture vessels were kept in a growth chamber with 16 hours photoperiod at about $26 \pm 2{ }^{\circ} \mathrm{C}$ with $25 \mu \mathrm{mol} \mathrm{m} \mathrm{m}^{-2} \mathrm{~s}^{-1}$ photon flux density provided by cool white fluorescent tubes and sub culturing was dome every 15 days.

\subsection{Regeneration of Cotyledonary Node Explants of Grass Pea on Different Concentrations of $B A P$}

In this experiment the in vitro regeneration capacity and shoot development of cotyledonary nodes of four genotypes of grass pea was evaluated on MS medium supplemented with different concentrations of BAP with $0.1 \mathrm{mg} / \mathrm{lNAA}$. Explants obtained from each genotype's cotyledonary node were cultured on MS media supplemented with different levels of BAP (0 $\mathrm{mg} / 1,1.0 \mathrm{mg} / \mathrm{L}, 2.0 \mathrm{mg} / \mathrm{L}$, and $3.0 \mathrm{mg} / \mathrm{L})$ with $0.1 \mathrm{mg} / 1 \mathrm{NAA}$. The experiment arranged factorially (4X3) in completely randomized design (CRD) with 15 explants per treatment where three explants cultured per jar and randomly placed on the shelves under uniform light and it was replicated five times. Data was collected on number of explants developed into shoot, number of shoots developed per explants and shoot length $(\mathrm{cm})$ after 10-15 days of culturing. A growth regulator free medium was used as control.

2.5.1 Effect of Different Concentrations of BAP and Kinetin on Shoot Multiplication of Genotype: IVAT-LS- 690

Under this experiment, MS medium containing different concentrations of BAP $(1,2,3$, and 
$4 \mathrm{mg} / \mathrm{l})$ in combination with $\mathrm{KT}(0,1,2$, and $3 \mathrm{mg} / \mathrm{l})$ was used and factorially arranged $(4 \times 4)$ in CRD, replicated five times, with 15 explants per treatment where three explants cultured per jar and randomly placed on shelves under uniform light. Data was collected on number of explants developed into shoot, shoots number per explants and shoots length $(\mathrm{cm})$ after 15 days. A growth regulator free medium was used as a control for these experiments too.

2.5.2 Effect of Different Concentrations of IAA and IBA on In Vitro Rooting of Genotype: IVAT-LS- 690

In this experiment two auxins (IBA and IAA) and their different concentrations were tested for in vitro rooting. The micro-shoots having a size of 2-3 $\mathrm{cm}$ were taken from the shoot multiplication experiment and cultured on half- strength MS medium supplemented with IBA( $0.0 \mathrm{mg} / 1,0.1 \mathrm{mg} / 1,0.25 \mathrm{mg} / 1,0.5 \mathrm{mg} / 1$, and $1 \mathrm{mg} / \mathrm{l})$ and IAA $(0.0 \mathrm{mg} / 1,0.1 \mathrm{mg} / 1,0.25$ $\mathrm{mg} / 1,0.5 \mathrm{mg} / 1$, and $1 \mathrm{mg} / \mathrm{l})$. The experiments were set individually for both auxins as a single factor experiments in CRD with 5 replications and 15 explants per treatment and placed on shelves under uniform light. Data was collected after 15 days on number of shoots induced rots, number of roots per shoot and root length $(\mathrm{cm})$.

\subsubsection{Acclimatization}

Plantlets with well-developed roots were taken from culture tubes and washed the roots in running tap water. They were transferred to plastic pots containing 1:2:1 ratio of top soil, sand, and compost, respectively and covered with polyethylene bags to maintain high humidity. The potted plantlets were kept in the culture room at $27 \pm 1^{\circ} \mathrm{C}$ and with a photon flux density of $50 \mu \mathrm{molm}^{-2} \mathrm{~s}^{-1}$. After a week, plantlets were transferred to larger pots containing soil and compost $(1: 1)$ and kept under field condition for another 20 days and their percentage of survival were determined according to method used by Fratini et al. (2009).

\subsection{Data Analysis}

Data analysis was done using SAS statistical package, version 9.2 (SAS Institute Inc. 2008).Duncan's new multiple range test was used to separate the means for significant effect at $5 \%$ probability.

\section{Results and Disscution}

\subsection{Regeneration Response of Cotyledonary Node Explants of Four Genotypes ofGrass Pea}

Of the four genotypes studied, the highest percentage (100\%) responses was obtained from IVAT-LS-690 at 2mg/1 BAP followed by IVAT-LS-655 (86.7\%) at $3 \mathrm{mg} / 1 \mathrm{BAP}$ while the least percentage $(33.3 \%)$ of response were obtained from IVATLS-B2 on BAP $1 \mathrm{mg} / 1$ (Table 1 ). 


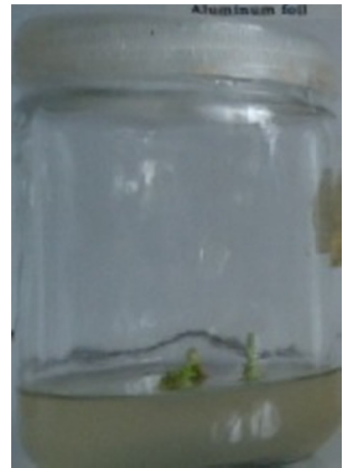

A

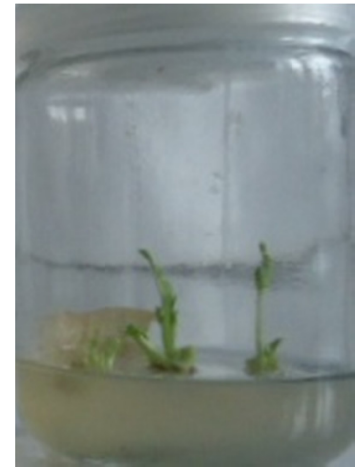

B

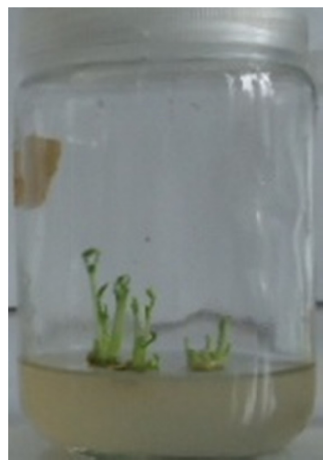

$\mathrm{C}$

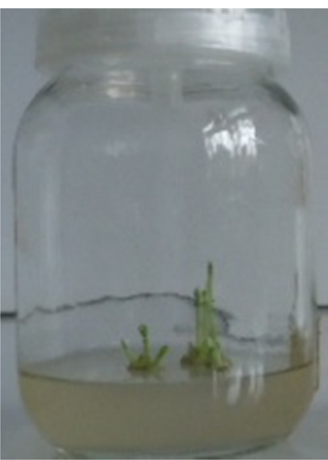

$\mathrm{D}$

Figure 1.Response of cotyledonary node cultured on MS shoot initiation media after eight days. (A) IVATLS-B2, (B) IVATLS-B1(C) IVAT-LS-690 and (D) IVAT-LS-655

For shoot formation capacity of all genotypes cotyledonary nodes after initiation, analysis of variance showed significant differences among the genotypes and BAP concentrations for all response variables; percentage of shoot development, average number of shoots per explants and average shoots length (Table 1).

At $1 \mathrm{mg} / \mathrm{l} \mathrm{BAP,} \mathrm{IVAT-LS-690attained} \mathrm{the} \mathrm{highest} \mathrm{percentage} \mathrm{of} \mathrm{shoot} \mathrm{development} \mathrm{and}$ maximum average shoot length, whereas IVATLS-B1showed maximum average number of shoots per explants. IVAT-LS-655 wasless responsive as compared to the rest three at this concentration. Best percentage of shoot development, maximum average shoots per explants and longest average shoot length were recorded from IVAT-LS-690at 2mg/1 BAP. At 3mg/1 BAP best percentage of shoot development was obtained from IVAT-LS-655while maximum average shoot per explants and average shoot length were obtained from IVATLS-B2.

Different results were observed among genotypes as BAP levels increases from $1 \mathrm{mg} / 1$ to 3 $\mathrm{mg} / \mathrm{l}$. Percentage of shoot formation increases with increasing BAP levels from 1-3 mg/l for genotypes IVATLS-B1 and IVAT-LS-655. However, for IVATLS-B2 and IVATLS-LS 690 it increase up to $2 \mathrm{mg} / 1$ and then decreased. Number of shoots per explant increases for all genotypes except for IVAT-LS-690as BAP levels increases while shoot length decreases with increasing BAP levels except IVAT-LS-655. 
Table 1. Shoot formation capacity of four genotypes on different concentrations of BAP with $0.1 \mathrm{mg} / 1 \mathrm{NAA}$

\begin{tabular}{|c|c|c|c|c|}
\hline Genotypes & $\begin{array}{l}\text { Hormone Con. } \\
(\mathrm{mg} / \mathrm{l}) \\
\text { BAP }\end{array}$ & $\begin{array}{l}\% \text { of Shoot } \\
\text { formation }\end{array}$ & $\begin{array}{l}\text { Mean No. of } \\
\text { Shoots/explant }\end{array}$ & $\begin{array}{l}\text { Mean Shoots } \\
\text { length }(\mathrm{cm})\end{array}$ \\
\hline IVATLS-B2 & 1 & $33.3 \mathrm{f}$ & $4.4 \mathrm{f}$ & $3.6 \mathrm{c}$ \\
\hline IVATLS-B1 & 1 & $53.3 \mathrm{edf}$ & $5.0 \mathrm{e}$ & $3.7 \mathrm{c}$ \\
\hline IVAT-LS-690 & 1 & $80.0 \mathrm{bac}$ & $3.5 \mathrm{~g}$ & $4.6 \mathrm{~b}$ \\
\hline IVAT-LS-655 & 1 & 40.0 ef & $1.8 \mathrm{~h}$ & $3.6 \mathrm{dc}$ \\
\hline IVATLS-B2 & 2 & $53.3 \mathrm{edf}$ & $9.2 \mathrm{c}$ & $4.5 b$ \\
\hline IVATLS-B1 & 2 & $53.3 \mathrm{edf}$ & $10.9 \mathrm{ba}$ & $5.0 \mathrm{a}$ \\
\hline IVAT-LS-690 & 2 & $100.0 \mathrm{a}$ & $11.4 \mathrm{a}$ & $5.0 \mathrm{a}$ \\
\hline IVAT-LS-655 & 2 & 40.0 ef & $6.5 \mathrm{~d}$ & $4.6 \mathrm{~b}$ \\
\hline IVATLS-B2 & 3 & $40.0 \mathrm{ef}$ & $10.9 \mathrm{ba}$ & $3.4 d$ \\
\hline IVATLS-B1 & 3 & $60.0 \mathrm{edc}$ & $11.2 \mathrm{ba}$ & $3.6 \mathrm{dc}$ \\
\hline IVAT-LS-690 & 3 & $73.3 \mathrm{bdc}$ & $10.6 b$ & $4.5 b$ \\
\hline IVAT-LS-655 & 3 & $86.7 \mathrm{ba}$ & $6.6 \mathrm{~d}$ & $4.7 b$ \\
\hline $\mathrm{CV}$ & & 7.03 & 5.61 & 4.17 \\
\hline
\end{tabular}

*Means with different letters in a column are significantly different at $\mathrm{p}=0.05$.

The cotyledonary node explants failed to regenerate shoots on MS basal medium free of growth regulators indicating the importance of external BAP in grass pea cotyledonay node culture initiation. But genotypes responses varied at each concentration of BAP. On top of this, high concentration of BAP induced multiple shoots but with stunted growth for all genotypes except IVAT-LS-655.This is because of an in vitro growth and morphogenesis of plants that are regulated by the interaction and balance between the growth regulators supplied in the medium, and the growth substances produced endogenously (George, 1993).

These result is in agreement with Ochatt (2001) who reported that the optimum hormonal combination for regeneration response of grass pea is genotype specific; genotype LB responded best on auxin-free medium with $5.0 \mathrm{mg} / 1 \mathrm{BAP}$, while colored-seeded genotypes responded best with $0.01 \mathrm{mg} / 1 \mathrm{NAA}$, plus $5.0 \mathrm{mg} / 1 \mathrm{BAP}$ for LIII, but $3.0 \mathrm{mg} / \mathrm{l} \mathrm{BAP}$ for L12 genotypes.

In general, among the four genotypes studied, IVAT-LS-690had the highest percentage of shoot development (100\%), maximum average shoot number (11.43) per explants, and longest average shoot length $(4.98 \mathrm{~cm})$ on $2.0 \mathrm{mg} / 1$ BAP level (Table 2). 


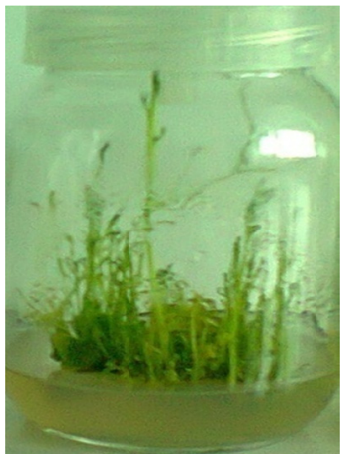

A

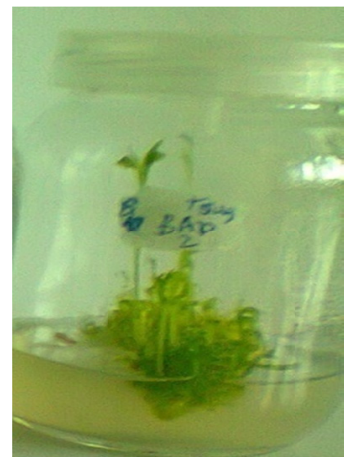

B

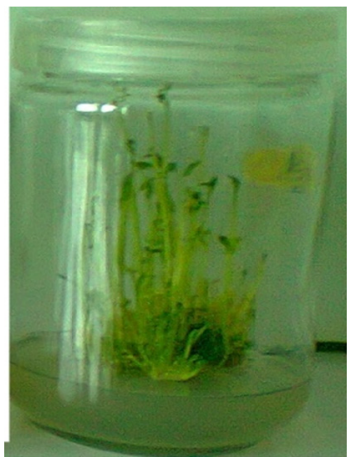

$\mathrm{C}$

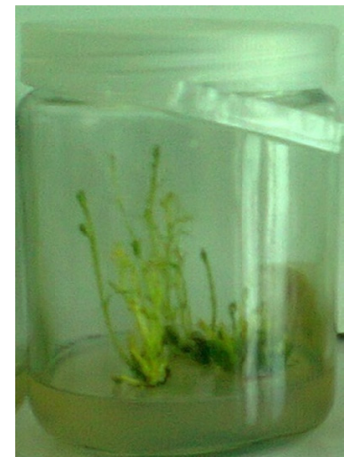

$\mathrm{D}$

Figure 2. Shoot development of IVATLS-B2 (A), IVATLS-B1 (B), IVAT-LS-690 (C) and IVAT-LS-655 (D) on MS medium supplemented with different level of BAP after two week of culturing

\subsection{Effect of Different Cytokines (BAP and Kn) and Their Concentrations on Shoot} Multiplication of IVAT-LS-690

In this study the combined effect of BAP and Kn concentrations on shoot multiplication of IVAT-LS-690 were compared. Nodal segments were taken from the plantlets of this genotype and cultured on MS medium containing different concentrations of BAP and Kn combinations. ANOVA revealed that statistically significant differences among the concentrations of BAP and $\mathrm{Kn}$ combination were observed for all response variables; percentage of culture regenerating shoots, average number of shoot per explants and average shoot length were computed (Table 2).

Table 2. The combined effects of BAP and Kn. on shoot multiplication of IVAT-LS-690

\begin{tabular}{lllll}
\hline $\begin{array}{l}\text { Hormone } \\
\text { Con. } \\
(\mathbf{m g} / \mathbf{l})\end{array}$ & $\begin{array}{l}\text { Hormone } \\
\text { Con. } \\
(\mathbf{m g} / \mathbf{l})\end{array}$ & $\begin{array}{l}\text { \% of } \\
\text { Shoot } \\
\text { formation }\end{array}$ & $\begin{array}{l}\text { Mean No. of } \\
\text { Shoots/explant }\end{array}$ & Mean Shoots length $(\mathbf{c m})$ \\
BAP & Kn. & & & \\
\hline 0 & 0 & 0 & 0 & 0 \\
1 & 0 & $33.3 \mathrm{~d}$ & $1.00 \mathrm{~g}$ & $3.20 \mathrm{f}$ \\
1 & 1 & $33.3 \mathrm{~d}$ & $1.00 \mathrm{~g}$ & $3.20 \mathrm{f}$ \\
1 & 2 & $44.4 \mathrm{dc}$ & $1.67 \mathrm{f}$ & $3.49 \mathrm{e}$ \\
1 & 3 & $77.8 \mathrm{bac}$ & $7.53 \mathrm{~d}$ & $4.38 \mathrm{c}$ \\
2 & 0 & $66.66 \mathrm{dba}$ & $9.06 \mathrm{c}$ & $4.43 \mathrm{c}$ \\
2 & 1 & $44.44 \mathrm{dc}$ & $2.17 \mathrm{f}$ & $3.52 \mathrm{e}$ \\
2 & 2 & $88.89 \mathrm{ba}$ & $11.17 \mathrm{a}$ & $5.00 \mathrm{a}$ \\
2 & 3 & $100.00 \mathrm{a}$ & $11.17 \mathrm{a}$ & $5.00 \mathrm{a}$ \\
\hline
\end{tabular}




\begin{tabular}{lllll}
\hline 3 & 0 & $58.89 \mathrm{bdc}$ & $10.39 \mathrm{~b}$ & $4.96 \mathrm{a}$ \\
3 & 1 & $100.00 \mathrm{a}$ & $11.50 \mathrm{a}$ & $4.96 \mathrm{a}$ \\
3 & 2 & $100.00 \mathrm{a}$ & $10.98 \mathrm{a}$ & $4.77 \mathrm{ba}$ \\
3 & 3 & $55.55 \mathrm{bdc}$ & $6.33 \mathrm{e}$ & $4.14 \mathrm{~d}$ \\
4 & 0 & $77.77 \mathrm{bac}$ & $9.50 \mathrm{c}$ & $4.60 \mathrm{bc}$ \\
4 & 1 & $55.55 \mathrm{bda}$ & $9.50 \mathrm{c}$ & $4.60 \mathrm{bc}$ \\
4 & 2 & $44.44 \mathrm{dc}$ & $6.33 \mathrm{e}$ & $4.90 \mathrm{a}$ \\
4 & 3 & $88.89 \mathrm{ba}$ & $9.50 \mathrm{c}$ & $4.60 \mathrm{bc}$ \\
\hline $\mathrm{CV}$ & & 6.2 & 4.7 & 7.9 \\
\hline
\end{tabular}

*Means with different letters in a column are significantly different. at $\mathrm{p}=0.05$.

All the treatments of Kn and BAP except control showed shoot development .However, the best response was observed on a medium supplemented with $3 \mathrm{mg} / \mathrm{l} \mathrm{BAP}+1 \mathrm{mg} / \mathrm{l} \mathrm{Kn}$ which resulted in the highest percentage of shoot regeneration (100\%) and highest number of shoots (11.5) per explants with a mean shoot length of $4.96 \mathrm{~cm}$ (Table 2) though, the result from this treatment is not statistically different from that of a medium supplemented with $2 \mathrm{mg} / \mathrm{l} \mathrm{BAP}+$ $2 \mathrm{mg} / \mathrm{l} \mathrm{Kn}, 2 \mathrm{mg} / \mathrm{l} \mathrm{BAP}+3 \mathrm{mg} / \mathrm{Kn} 3 \mathrm{mg} / \mathrm{l} \mathrm{BAP}+2 \mathrm{mg} / \mathrm{K} \mathrm{Kn}$. Statistically the second best result of this experiment was obtained from medium supplemented with $3 \mathrm{mg} / \mathrm{l} \mathrm{BAP}+0 \mathrm{mg} / \mathrm{l}$ $\mathrm{Kn}$.

These results are in agreement with the results of Sevimay et al. (2005) who obtained best results from a medium supplemented with BAP and KT combinations. Debnath et al. (2010) also obtained best shooting in a medium supplemented with a combination of BAP and Kn. though NAA was used additionally. But Barik et al. (2004) reported maximum number of shoots per explants $(11.3)$ and longest shoot $(4.9 \mathrm{~cm})$ on BAP alone at $2 \mathrm{mg} / 1$ for grass pea species. On the other hand, Sarker et al. (2003) obtained healthy shoots with well developed leaves on MS medium supplemented with $2 \mathrm{mg} / \mathrm{l}$ of BAP $+\mathrm{mg} / \mathrm{l} \mathrm{Kn}$, though various concentrations and combinations of these growth hormones initiated shoot formation for lentils (Lens culinaris) a close species of grass pea.

In general, the results demonstrated that highest mean number of shoot per explants and longest average shoot was obtained from MS medium containing $3 \mathrm{mg} / 1 \mathrm{BAP}+1 \mathrm{mg} / 1 \mathrm{Kn}$. Even though, BAP alone at $3 \mathrm{mg} / \mathrm{l}$ was almost similar to the second best result of BAP and Kn combination with better average shoot length but plantlets from BAP and Kn combination appeared more healthy and green (Figure 3). In addition to this, percentage of shoot development was lower on BAP alone. 


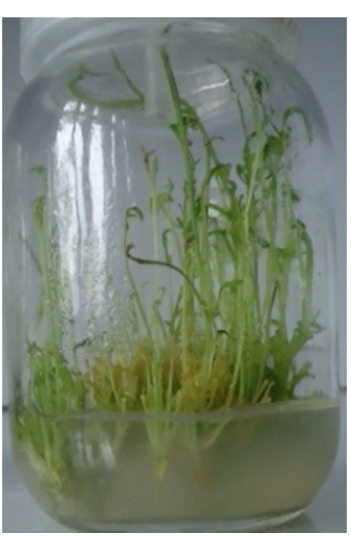

A

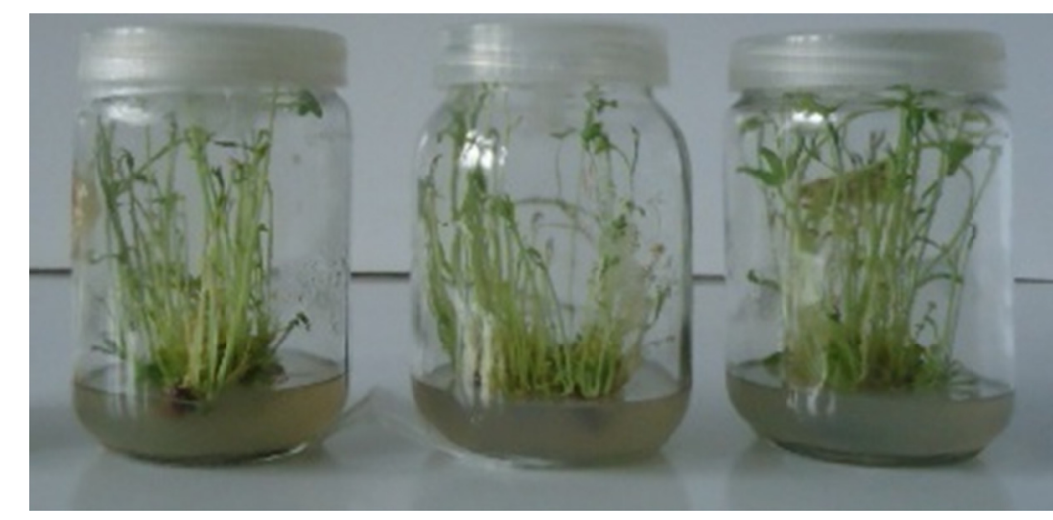

B
$\mathrm{C}$

Figure 3. Shoot multiplication on MS medium supplemented with BAP and Kn combination $\mathrm{A}=\mathrm{MS}+3 \mathrm{mg} / \mathrm{BAP}+0 \mathrm{mg} / \mathrm{Kn}, \mathrm{B}=\mathrm{MS}+3 \mathrm{mg} / \mathrm{l} \mathrm{BAP}+1.0 \mathrm{mg} / 1 \mathrm{Kn}, \mathrm{C}=\mathrm{MS}+2 \mathrm{mg} / \mathrm{Kn}+2$ $\mathrm{mg} / \mathrm{l} \mathrm{BAP}, \mathrm{D}=\mathrm{MS}+2 \mathrm{mg} / \mathrm{l} \mathrm{Kn}+3 \mathrm{mg} / \mathrm{l} \mathrm{BAP}$

\subsection{Effect of IAA and IBA Concentrations on In Vitro Rooting of IVAT-LS-690}

For this experiment, micro shoots grown with BAP $3 \mathrm{mg} / 1+\mathrm{Kn} 1 \mathrm{mg} / 1$ that showed the best shoot number as well as shoot length were used for to rooting study. Half strength MS medium augmented with various concentrations of IAA and IBA individually were tried in two experiments to induce rooting.

Analysis of variance from this experiment showed significance difference among treatments (IAA and IBA concentration) for all response variables including percentage of rooting, number of root per shoot, and average root length.

On half-strength MS medium supplemented with different levels of IAA, the highest percentage of rooting $(80 \%)$, maximum root number (5.6 roots per shoot), and longest average root length $(4.9 \mathrm{~cm})$ was obtained at $1 \mathrm{mg} / 1 \mathrm{IAA}$, while shoots cultured on media devoid of auxins failed to form roots on both experiments. Even though, there was no statistically significant difference among $0.1,0.25$, and $0.5 \mathrm{mg} / 1$ concentration; percentage of rooting, number of roots per shoot and average roots length were increased with increased concentration of IAA (Table 3 ).

Table 3. Effects of IAA concentration on in vitro rooting of genotype IVAT-LS-690

\begin{tabular}{llll}
\hline $\begin{array}{l}\text { IAA Con. } \\
(\mathbf{m g} / \mathbf{l})\end{array}$ & \% of rooting & $\begin{array}{l}\text { Mean No. of } \\
\text { roots/shoot }\end{array}$ & $\begin{array}{l}\text { Mean No. of } \\
\text { roots length }(\mathbf{c m})\end{array}$ \\
\hline 0 & 0 & 0 & 0 \\
0.1 & $40.00 \mathrm{~b}$ & $1.20 \mathrm{c}$ & $3.68 \mathrm{~b}$ \\
0.25 & $46.66 \mathrm{~b}$ & $3.40 \mathrm{~b}$ & $3.97 \mathrm{~b}$ \\
0.5 & $53.33 \mathrm{~b}$ & $3.50 \mathrm{~b}$ & $3.99 \mathrm{~b}$ \\
1.0 & $80.00 \mathrm{a}$ & $5.60 \mathrm{a}$ & $4.90 \mathrm{a}$ \\
\hline
\end{tabular}



$\mathrm{CV}$
9.17
11.54
5.38

*Means with different letters in a column are significantly different, at $\mathrm{p}=0.05$.

On the other hand, from half-strength MS medium supplemented with different concentrations of IBA; highest percentage of rooting $(86.66 \%)$, maximum root number $(6$ roots per shoot), and longest average root length $(4.91 \mathrm{~cm})$ were recorded on $0.5 \mathrm{mg} / 1 \mathrm{IBA}$ (Table 4). Concentrations of auxins exceeding $0.5 \mathrm{mg} / 1$ showed a reduction in rooting response for IBA whereas rooting response increased with increasing concentration of IAA.

Table 4. Effect of IBA concentration on in vitro rooting of IVAT-LS-690

\begin{tabular}{llll}
\hline $\begin{array}{l}\text { IBA Con. } \\
(\mathbf{m g} / \mathbf{l})\end{array}$ & \%age of rooting & $\begin{array}{l}\text { Mean No. of } \\
\text { roots/shoot }\end{array}$ & $\begin{array}{l}\text { Mean No. of } \\
\text { roots length }(\mathbf{c m})\end{array}$ \\
\hline 0 & 0 & 0 & 0 \\
0.1 & $46.7 \mathrm{~b}$ & $1.2 \mathrm{c}$ & $3.7 \mathrm{c}$ \\
0.25 & $40.0 \mathrm{~b}$ & $3.5 \mathrm{~b}$ & $4.0 \mathrm{~b}$ \\
0.5 & $86.7 \mathrm{a}$ & $6.0 \mathrm{a}$ & $4.9 \mathrm{a}$ \\
1.0 & $53.3 \mathrm{~b}$ & $3.4 \mathrm{~b}$ & $3.9 \mathrm{cb}$ \\
$\mathrm{CV}$ & 8.17 & 10.27 & 5.24 \\
\hline
\end{tabular}

*Means with different letters in a column are significantly different.at $\mathrm{p}=0.05$.

These results are similar to Ochatt et al. (2001), who observed high rooting percentage (90\%) on half-strength MS medium supplemented with $1 \mathrm{mg} / 1$ IAA or $0.01 \mathrm{mg} / \mathrm{l} \mathrm{NAA}$ but, in contrast to Dayal et al. (2003) who obtained best rooting on medium supplemented with 2.2 mg/l IAA. These authors claimed that they observed $100 \%$ rooting percentage on this concentration. Similarly, Mohan and Krishnamurthy (1998) also noticed that 80-85 survival percentage on half-strength MS medium with IBA $(0.5 \mathrm{mg} / \mathrm{l})$.

The rooted shoots on half-MS media supplemented with IBA, showed fast elongation of roots with numerous thin laterals whereas only few elongation with callus like structure were observed on media supplemented with IAA (Figures 4 and 5). Based on the fact that these experiments were done in the same time under the same condition, of the two auxins tested, IBA was found to be better, as compared to IAA for in vitro rooting of this specific genotype. This is in accordance with previous report of Muller et al.(2005) who reports better performance IBA over IAA for in vitro rooting of many legumes.

Difference in metabolism, differences in transport and higher stability of IBA over IAA is the most probable reason for better performance of IBA as compared to IAA (Epstein \& Muller 2012). 


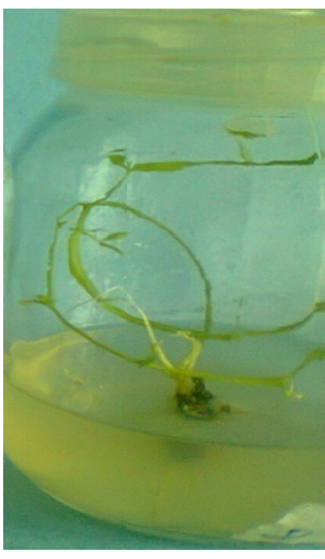

IAA $0.1 \mathrm{mg} / 1$

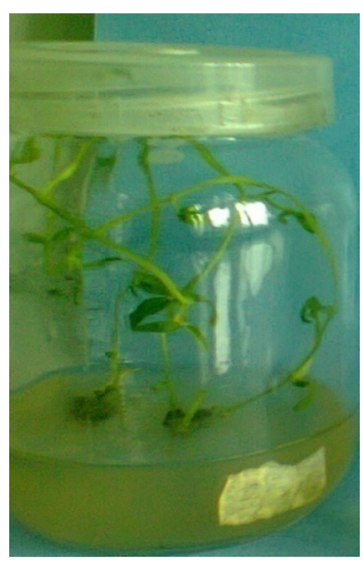

IAA $0.25 \mathrm{mg} / 1$

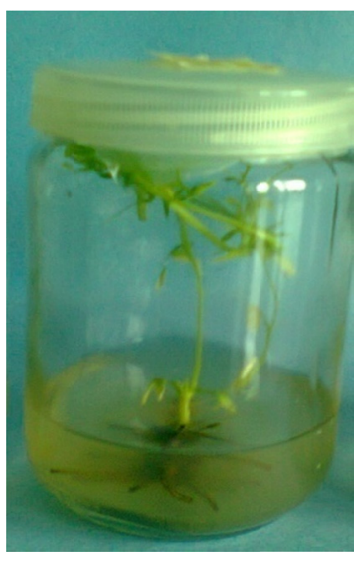

IAA $0.5 \mathrm{mg} / 1$

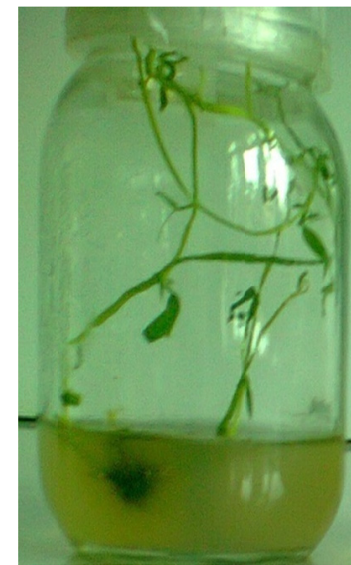

IAA $1.0 \mathrm{mg} / 1$

Figure 2. In vitro rooting of IVAT-LS-690 on different concentration of IAA

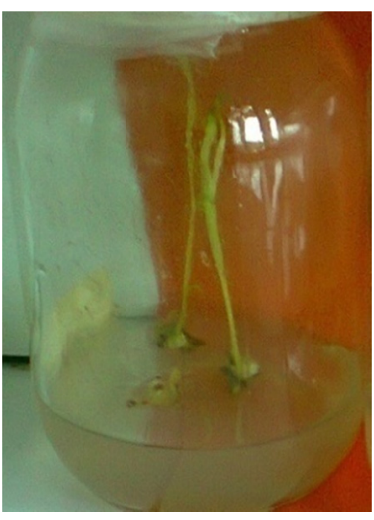

IBA0.1mg/1

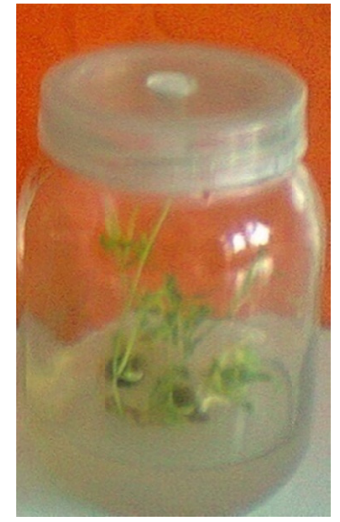

IBA0.25mg

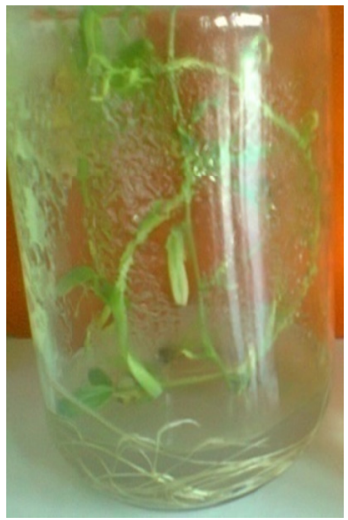

IBA $0.5 \mathrm{mg} / 1$

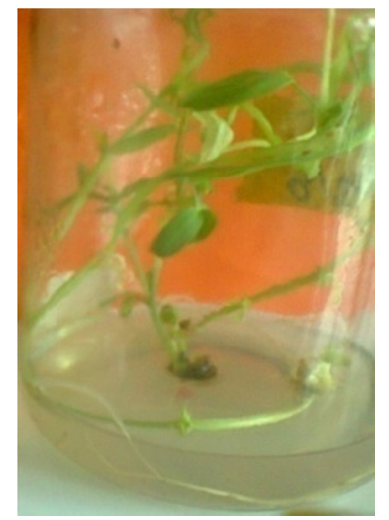

IBA1mg/l

Figure 3. In vitro rooting of IVAT-LS-690 on different concentration of IBA

\subsection{Acclimatization}

Best rooted shoots were transferred into pots containing 1:2:1 ratio of top oil, sand, and compost, respectively. As recommended by Fratini et al.(2009). The transferred plantlets showed $60 \%$ survival and looked healthy after three weeks of acclimatization. But among the survived plantlets some of them showed fast elongation with light green color (Figure 6). This may be due to low amount of light which led to etiolation. The low rate of survival could be due to the delicate nature of roots of this crop which make them susceptible to mechanical injury during transfer that decreases the survival rate of the plantlets.

Fratini et al. (2009) reported 67\% survival and Barik et al. (2004) reported 78\% survival on their works but in our case only $60 \%$ were survived. Time period difference, genotype and direct transfer of rooted plantlets into the pot could be the possible reasons for the difference. 


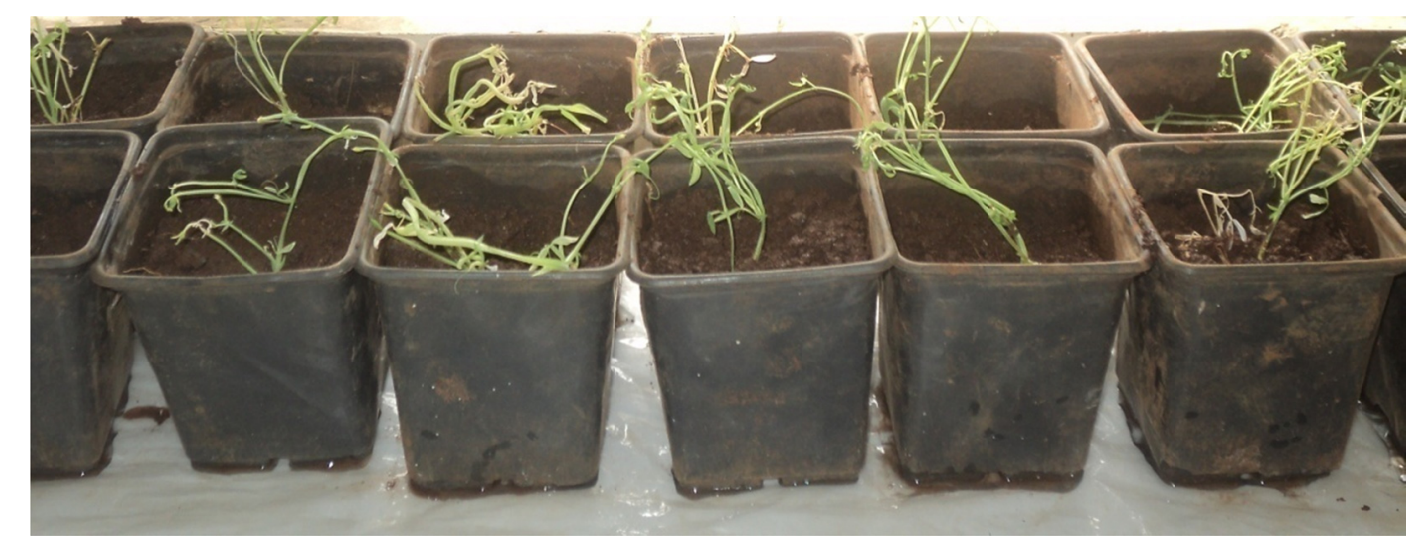

Figure 4. Acclimatized plantlets in pots under normal field condition

\section{Summary and Conculusion}

In vitro regeneration capacity of four grass pea genotypes (VATLS-LS -B2, IVATLS-LS -B1, IVAT-LS- 690, and IVAT-LS-655) was evaluated on three concentrations of BAP (1 mg/1, 2 $\mathrm{mg} / \mathrm{l}$ and $3 \mathrm{mg} / \mathrm{l}$ ) in combination with $0.1 \mathrm{mg} / \mathrm{l} \mathrm{NAA}$ and the best responded genotype was selected based on its performance on shoot initiation media to determine the effect of different cytokinines and auxins concentrations for in vitro shoot multiplication and rooting.

The results revealed that both genotype and plat growth regulators concentrations have significance effect on regeneration capacity of cotyledonary nodes of the genotypes. Each genotype responded differently on the same concentration of PLG and among them IVAT LS 690 showed superiority performance over the others and was selected for subsequent experiments.

For in vitro shoot multiplication of genotype IVAT LS 690 among different concentrations of BAP and Kn combinations tested, best shoot multiplication was obtained on MS medium supplemented with $3 \mathrm{mg} / \mathrm{l} \mathrm{BAP}+1 \mathrm{mg} / \mathrm{l} \mathrm{Kn}$ even though it was not statistically different from the other treatments, i.e., $2 \mathrm{mg} / \mathrm{l} \mathrm{BAP}+2 \mathrm{mg} / \mathrm{Kn}, 2 \mathrm{mg} / \mathrm{l} \mathrm{BAP}+3 \mathrm{mg} / \mathrm{l} \mathrm{Kn}$ and $3 \mathrm{mg} / \mathrm{l} \mathrm{BAP}$ $+2 \mathrm{mg} / \mathrm{l} \mathrm{Kn}$.

Among the different concentrations tested for the in vitro rooting of this genotype, the best rooting was obtained on half-strength MS medium supplemented with $1 \mathrm{mg} / 1$ IAA and $0.5 \mathrm{mg} / 1$ of IBA. The rooted shoots gave considerable number of roots on both auxins tested but IBA gave better rooting as compared to IAA.

Based on the result of present study the following conclusions can be drawn;

$>$ Different results were obtained from the four genotypes tested for in vitro shoot proliferation response and IVAT-LS-690 on $2 \mathrm{mg} / \mathrm{l}$ BAP with $0.1 \mathrm{NAA}$ was found to be the best among the tested genotypes indicating that both genotype and PGL concentration play a crucial role on in vitro shoot regeneration capacity of cotyledonary nodes.

$>$ For in vitro shoot multiplication of IVAT-LS-690, MS medium supplemented with $3 \mathrm{mg} / \mathrm{l}$ BAP $+1 \mathrm{mg} / \mathrm{lKn}$ gave the highest number of shoots per explants on a medium containing 2 $\mathrm{mg} / \mathrm{l} \mathrm{BAP}+1 \mathrm{mg} / \mathrm{lKn}$ which created a synergetic effect and interact with its endogenous counterpart to induce best shooting. 
$>$ Of the two auxins concentrations tested for in vitro rooting of IVAT-LS-690, halfstrength MS medium supplemented with $0.5 \mathrm{mg} / 1$ IBA gave the highest root number per shoot with over all better performance than IAA. Differences in transport and higher stability or genotype specificity could be the most probable reason for better performance of IBA for in vitro rooting of this specific genotype (Epstein \& Muller, 2012).

Based on the results of the present study, we suggest the following:

$>$ Both genotype and PGL concentration play a crucial role on in vitro shoot regeneration capacity of cotyledonary node. Therefore, there is need to use different concentrations of PGL for different genotypes. Based on this $2 \mathrm{mg} / 1 \mathrm{BAP}+0.1 \mathrm{NAA}$ could be used for shoot initiation

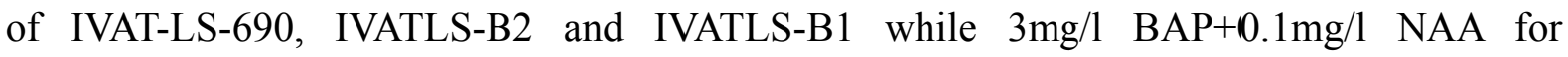
IVAT-LS-655.

$>$ MS medium supplemented with $3 \mathrm{mg} / \mathrm{l} \mathrm{BAP}+1 \mathrm{mg} / \mathrm{l} \mathrm{K}$ could be used for shoot multiplication of IVAT-LS-690 while half -strength MS medium supplemented with $1 \mathrm{mg} / \mathrm{l}$ IAA or $0.5 \mathrm{mg} / 1 \mathrm{IBA}$ could be used for in vitro rooting.

$>$ The optimized protocol could be used as a baseline for further studies of in vitro regeneration of grass pea

\section{References}

Babaoglu, M., Davey, M. R., \& Power, J. B. (2000). Genetic engineering of grain legumes: key transformation events.AgBiotechNet, 2, 1-8. Wallingford: CAB International.pp.532-541.

Barik, D. P., Mohapatra, U., \& Chand,P. K. (2005). Transgenic Grass pea (Lathyrus sativus L.): Factors influencing Agrobacterium mediated transformation and regeneration. Plant Cell Rep, 24, 523-531.https://doi.org/10.1007/s00299-005-0957-5

Campbell, C. G. (1997). Grass pea (Lathyrus sativus L.) Promoting the conservation and use of underutilized and neglected crops. Institute of Plant Genetics and Crop Plant Research, Gatersleben/International Plant Genetic Resources Institute, Rome, Italy.

Central Statistical Authority (CSA). (2010). Statistical Abstract of Ethiopia 2010. Ethiopian Agricultural Research Organization, Addis Ababa, Ethiopia.

Debnath S. C., Mckenzie D. B., \& Mcrae, K. B. (2010). Callus induction and shoot regeneration from stem, rachis and leaf explants in beach pea (Lathyrus japonicasWilld). $J$. Pl.Biochemist. Biotech, 10(1), 57-60.https://doi.org/10.1007/BF03263108

Dejene, G., \& Li jalem K. (2012). Genetic improvement of grass pea (Lathyrus sativus) in Ethiopia. Plant Breeding, 131, 231-236. https://doi.org/10.1111/j.1439-0523.2011.01935.x

Epstein \& Muller, J. L. (2012). Indole-3-butyric acid in plants; occurrence, biosynthesis, Metabolism and transport. Physiologia plantarum, 88,382-389.https://doi.org/10.1111/j.1399-3054.1993.tb05513.x

Fratini, R., \& Ruiz, M. L. (2009). A rooting procedure for lentil (Lens culinaris Medik.) and other hypogeous legumes (pea, chickpea and lathyrus) based on explant polarity. Pl. Cell Rep., 21, 726-32.

Gomez, K. A., \& Gomez, A. A. (1984). Statistical procedure for agricultural research. New York: John Wiley \& Sons.

Girma, D. (2010). Ethiopian Grass Pea (Lathyrus sativus L.) Started the Genomics Era. 
Lambert Academic Publishing, Koeln, Germany., 1, 34-35.

Muller, J. L. (2005). Analysis of indole-3-butyric acid- adventitious root formation on Arabidopsis stem segments. Journal of Exp. Bot, 56(418), 2095-2105. https://doi.org/10.1093/jxb/eri208

Ochatt, S., Duriew, P., Jacas, L., \& Pontecaille, C. (2001). Protoplast, cell and tissue cultures for the biotechnological breeding of grass pea (Lathyrus sativus L.). Lathyrus Lathyrism Newsletter, 2, 35-38.

Olhoft, P. M., Lin, K., Galbraith, J., Nielsen, N. C., \& Somers, D. A. (2001). The role of thiol compounds in increasing Agrobacterium-mediated transformation of soybean cotyledonary-node cells. Plant Cell Rep,20, 731-737.https://doi.org/10.1007/s002990100388

Sarker, R. H., Barkat, M. M., Ashapurno, B., Shirin, M., Mouful, N., Rehana, H., \& Hoque, M. I. (2003). In vitro Regeneration in Lentil (Lens culinaris Medik.). Plant Tissue Cult,13(2), 155-63.

Sevimay, C. S., Khawar, K. M., \& Yuzbasioglu, E. (2005). Adventitious shoot regeneration from different explants of wild lentil (Lens culinaris subsp. orientalis). Biotechnol. \&Biotechnol. Equip, 19, 2 Suppl. 2, 46-49.https://doi.org/10.1080/13102818.2005.10817189

Smartt, J. (1990).Grain Legumes: Evolution and Genetic Resources. Cambridge University Press, Cambridge, UK. https://doi.org/10.1017/CBO9780511525483

Tiwari, K. R., \& Campbell, C. G. (1996). Inheritance of neurotoxin (ODAP) content, flower and seed coat colour in grass pea (Lathyrus sativusL.). Euphytica, 91, 195-203.

VazPatto, M. C., Skiba, B., Pang, K., Ochatt, J., Lambein, F., \& Rubiales, D. (2006). Lathyrus improvement for resistance against biotic and abiotic stresses: From classical breeding to $\begin{array}{llll}\text { marker assisted } \quad \text { selection. } & \text { Euphytica, 133-147. }\end{array}$ https://doi.org/10.1007/s10681-006-3607-2

Wuletaw, T. (2003). Stability of grasspea (Lathyrus sativusL.) varieties for ODAP content and grain yield in Ethiopia. Lathyrus Lathyrism Newsletter, 3, 32-33

Wuletaw, T., \& Endashaw, B. (2001). Factor analysis of components of yield in grass pea (Latyrus sativusL). Lathyrus lathyrism newsletter, 2, 91-93.

Yigzaw, L., Gorton, Akalu, G., \& Solomon, T. (2001).Fermentation of teff (Eragrostistef), grass-pea (Lathyrus sativus), and their mixtures: Aspects of nutrition and food safety. Lathyrus lathyrism news letter, 2, 8-9.

Zambre, M., Chowdhury, B., Kuo, Y. H., Van Montagu, M., Angenon, G., \& Lambein, F. (2002). Prolific regeneration of fertile plants from green nodular callus induced from meristematic tissues in Lathyrus sativus L (grass pea). Plant Sci, 163, 1107-11. https://doi.org/10.1016/S0168-9452(02)00319-9

\section{Copyright Disclaimer}

Copyright reserved by the author(s).

This article is an open-access article distributed under the terms and conditions of the Creative Commons Attribution license (http://creativecommons.org/licenses/by/3.0/). 